\title{
Using Reflective Online Diaries to Enhance Teaching, Learning and Assessment in Online Apprenticeships
}

\author{
Aine Doherty ${ }^{* 1}$ \\ Chris McLaughlin² \\ ${ }^{1}$ IT Sligo \\ ${ }^{2}$ University of Ulster
}

\section{Abstract}

This paper explored the use of reflective online diaries to enhance teaching, learning and assessment in the context of an apprenticeship programme delivered online. An action research mixed methodology was employed; including qualitative reflective practice and a quantitative survey of students enrolled on a sales module over four academic years. Quantitative data analysis included Spearman Rank-Order Correlations, Exploratory Factor Analysis and Path Analysis using IBM AMOS v25 and explored the relationship between each student cohort and other key factors including assessment value, manageability, frequency, student enhancement and module satisfaction.

The outcome is a conceptualisation of a student enhancement and module satisfaction process, in a tested framework model. The findings indicate student enhancement's crucial role in predicting student satisfaction with the module; the more an apprentice learner perceives a reflective assessment activity will inform different areas of their overall learning, the more likely they are to be satisfied with the module. The use of reflective online diaries also demonstrates their role in overcoming challenges associated with online teaching and learning. The benefits of critical reflective practice for educators are also reinforced, where the outcome can lead to an enhancement in teaching, learning and assessment.

This research significantly adds to growing evidence that ePortfolio based learning has potential to support many higher education objectives connected to achievement of knowledge, skills, and competence by third level learners. The implications advocate for higher education institutions to create opportunities for educators to test new assessment methods, strategies, and tactics.

\section{Introduction}

The traditional apprenticeship conducts learning through traditional classroom-based pedagogy. However, contemporary teaching practices have led to the development of apprenticeship programmes delivered online. This delivery mechanism, while cost efficient and effective, is also believed to promote accessible, convenient, and flexible education opportunities for traditional and non-traditional learners (Aslanian and Clinefelter, 2013). But without physical interaction, online learning faces its own challenges. ePortfolios, or reflective online diaries, are an ideal teaching, learning and assessment activity to address the challenges associated with online teaching and learning, and are increasingly used in higher education as means of facilitating the assessment of learning (Farrell, 2018). An ePortfolio is defined as multifaceted; it can be "a technology, a pedagogical approach, and a process, as well as a product" (Chen and Black, 2010). The purpose of an ePortfolio ranges from 
tracking student development within a programme, to finding a job, or monitoring student performance. However, most often it is used to collect evidence of a student's learning and engagement through reflection (Chen et al., 2016).

While research exists on the use of reflective online diaries in education (Donaldson et al., 2018; Farrell, 2018; Farrell and Seery, 2019; Scholz et al, 2017; Wuetherick and Dickinson, 2015); this study explores their usefulness in the context of an apprenticeship programme delivered online in Ireland. This research examines if reflective online diaries can enhance teaching, learning and assessment in the context of an apprenticeship programme delivered online. Whilst teaching, learning and assessment are intrinsic to one another (QQI, 2013), they have been explored individually; hence, the research questions are; Can reflective online diaries enhance student learning experiences?; Can reflective online diaries enhance student assessment perceptions?; and can reflective online diaries enhance teaching? Findings provide evidence to generate a discussion regarding past research and generate both implications and recommendations for educational practice and future research. This study addresses a gap in literature related to the potential positive impact of reflection within ePortfolios on student learning (Donaldson, 2018). The outcome is a conceptualisation of a student enhancement and module satisfaction process, in a tested framework model; few studies have approached research in this area in such a way. The implications advocate higher education institutions (HEIs) must create opportunities for educators to test new assessment methods, strategies, and tactics. A review of relevant literature is presented first, followed by an outline of the research design employed and a discussion of the findings.

\section{Literature Review}

\subsection{Online Teaching \& Learning}

The growth of online learning has been significant over the past three decades (Martin et al., 2017). Higher education providers now deliver programmes of learning to students all over the world, resulting in a proliferation of learning opportunities (Naidu, 2019). The COVID19 pandemic accelerated the move from traditional campus-based teaching and learning, to the online mode of teaching and learning. The concerns of lecturer's ability to support successful student learning when teaching online are documented in literature (McTaggart et al., 2018). Hence, what was once a challenge only for those teaching online, became a daily struggle for all instructors.

While practices used in traditional classroom-based teaching can be adapted for the online context, teaching online is not the same; therefore, a "one size fits all" approach will not be successful in engaging all learners. Online learning is criticised because some learners go through the entire experience feeling isolated. Without any physical peer interaction, learners can feel almost invisible to their classmates and instructors (Gillett-Swan, 2017). Online learners experience challenges related to; digital competency, engagement, access, learning community support, group assessments and isolation. However, pedagogical strategies for supporting online learners are available to assist instructors to develop online learning communities and facilitate interactive and engaging learning experiences, thereby reducing these barriers (Gillett-Swan, 2017). 


\subsection{Teaching, Learning and Assessment Strategy}

Pedagogy comprises the teaching, learning and assessment methods adopted by an instructor. There are several theoretical perspectives, each with a slightly different definition of learning; the instructors' facilitation of student learning is dependent on the theory they hold (Carlile and Jordan, 2005). Thus, pedagogy is intrinsic to instructors. The link between teaching, learning and assessment is palpable, where "effective assessment is intrinsic both to effective teaching and learning", the activities of one, directly affect the others (QQI, 2013, p. 7). Thus teaching, learning and assessment strategy is a fundamental pillar of higher education.

In designing module level assessment tasks, educators in Ireland are guided by the QQI (2013) Assessment and Standards principles, usually disseminated within organisations as local guidance or policy, and take many factors into consideration including: QQI level, programme learning outcomes, programme assessment strategy and schedule, module learning outcomes and the number of credits. There are also context specific factors, such as the nature and appropriateness of the assessment instrument (whether formative or summative, or a combination thereof), the weighted value attributed to assessment, manageability on the students part, and any individual student cohort characteristics, such as whether the students are full time, part-time, on-campus or off-campus, class room based, blended, or online, apprentice or traditional (Department of Education and Skills, 2011; QQI, 2013). Additionally, choice of assessment method needs to consider the make-up of students, over other considerations such as infrastructure, resource constraints, or inflexible requirements (Fry et al., 2009).

Student enhancement is defined by Harvey and Green (1993, cited in Williams, 2016, p. 97) as 'the augmentation or improvement of learners' attributes, knowledge, ability, skills and potential", however few studies have examined its evaluation at a modular level within third level programmes. QQI documentation focuses on the enhancement of the providers' quality assurance procedures suggesting in turn this will enhance the teaching and learning environment for students (QQI, 2013, 2014, 2016). QQI emphasise HEIs should create opportunities to enhance lecturer expertise and to facilitate them in developing and testing new and appropriate assessment strategies to cope with emerging challenges.

There is growing evidence that ePortfolio based learning has the potential to support many higher education objectives by developing the learner's critical reflection skills which are highly transferable (Farrell, 2018; Jenson, 2011). However, empirical evidence surrounding ePortfolios from Irish HEIs is limited; Farrell (2018) highlights the need for academic staff to be supported in their professional development of ePortfolio usage and suggests funding for empirical research on ePortfolios would facilitate an understanding of their purpose and advantages.

\subsection{Reflective Online Diaries}

'EPortfolio' is an all-encompassing term used to describe the process of collecting evidence of a student's learning and engagement through reflection (Chen et al., 2016). ePortfolios are frequently used to document the student experience while on placement, or in professional practice, or to support the students transition to the workplace and develop their employability skills (Farrell, 2018). For apprenticeship programmes, ePortfolios allow students to reflect on their personal learning journey and can include samples or artefacts as 
evidence of student learning. However, sharing samples or artefacts is not feasible on every higher education programme. Professional apprenticeship programmes continue to grow in Ireland (Generation Apprenticeship, 2021), consequently many apprentice students are employed in industries which are bound by stringent General Data Protection Regulations (GDPR). GDPR limits the information which can be shared outside an employer's data storage security measures; resulting in the use of text based ePortfolios in these circumstances. Given these GDPR limitations, this study adopts the term 'Reflective Online Diary' to describe its version of a reflective, text based ePortfolio. This description was appropriate due to its informal disposition, to ensure student understanding of the assessment tool.

Reflective online diaries have potential to provide a formal way to credit students for recognising the value of their learning and are an effective way for lecturers to check if students are engaged with content. Learner-instructor interaction refers to a two-way communication which can take the form of guidance, evaluation, or encouragement (Kuo et al., 2014). Consequently, digital assessment tools such as reflective online diaries can facilitate interaction, foster a relationship between the instructor and learner(s) (Gillett-Swan, 2017) and enhance the learning experience of students (Fry et al., 2009).

\subsection{Reflection and Feedback}

Adopting reflective online diaries as an assessment tool in an online apprenticeship programme gives students the opportunity to reflect on their learning in a structured and accredited way, whereby learners are allocated continuous assessment marks for their active engagement with the tool. This engagement provides authentic meaning, because it represents the education students have not only received, but also how they have interpreted the learning process and personalised it for themselves (Chen et al., 2016). Reflective writing within online diaries have many benefits ranging from; supporting independent learning; providing a space for students to locate and order their thoughts; encouraging deep learning and selfassessment (Farrell and Seery, 2019); and counteracting possible 'spoon feeding' associated with handouts or lecture notes and (Moon, 2010). Research indicates ePortfolios can enable students to learn in a self-regulated way (Jenson, 2011). In line with QQI Assessment guidelines (2013, p. 7) "the effort required of a learner to complete an assessment task should be proportional to the associated educational benefit to him or her"; thus, in adopting reflective online diaries the manageability, assessment value and frequency of completion should be considered (Race, 2020).

Reflection turns experience into learning (Boud et al., 1985) and comprises the examination and analysis of an experience, which can then be supported by feedback (Fry et al., 2009). Therefore, formative assessment supports learning and should prioritise formative feedback as an essential part of any programme of education and training (QQI, 2013). Reflective online diaries allow a lecturer to provide ongoing formative feedback to individual students throughout their learning. This feedback facilitates the development of self-assessment and reflection in learning, promotes peer and tutor dialogue around learning, helps to clarify what good performance is and provides information to teachers that is used to help shape their teaching (Nicol and Macfarlane-Dick, 2006).

Lecturers face many challenges when moving into the online teaching space including low levels of support available to academic staff, personal anxiety, and limited opportunities to seek peer advice to improve online teaching pedagogy (McTaggart et al., 2016). Reflective 
online dairies pose a solution to address these challenges, by permitting the lecturer to gauge students understanding of theory and content delivered online, and to retrospectively adapt pedagogy and assessment strategy if concerns arise. The reflective online diaries therefore enhance the feedback process, not only for the learner, but for the teacher too, suggesting they are an ideal assessment tool to address the challenges associated with online teaching and learning. They are also an effective way to collect data, which can be used to reflect on one's pedagogical approach.

\subsection{Student Engagement and Satisfaction}

Student engagement indicators are identified and evaluated within the annual Irish Survey of Student Engagement (ISSE). The survey is completed by first and final year students, with annual results published for each participating HEI in Ireland. The ISSE data allows for comparison between Irish HEIs, but it does not provide modular level information which might support instructors to monitor student enhancement, engagement, and satisfaction within their own modules. Instead, quality assurance (QA) procedural surveys administered to students on completion of a module help to address this gap. HEIs in Ireland adhere to statutory QA Guidelines outlined by the QQI (2016). Ongoing reviews and self-evaluations of quality are a fundamental way to support the development of a quality culture within Irish HEIs. QA is also a term used to describe the enhancement of students during their third level studies, where HEIs are asked to monitor the teaching, learning and assessment strategies used to enhance student learning periodically. QQI QA guidelines require students to give feedback on completion of each programme module, usually through a self-administered survey whereby data collected supports QA and the management of the student learning experience (QQI, 2016).

In the UK, The National Student Survey (NSS) asks 27 questions on eight aspects of the student experience: the teaching on my course, learning opportunities, assessment and feedback, academic support, organisation, and management, learning resources, learning community, student voice and overall satisfaction (NSS, 2020). Short in length and written in first person with the respondent in mind, the UK student survey had a response rate of $69 \%$ in 2020 , of which $83 \%$ of students agreed "overall-I am satisfied with the quality of the course" (Office for Students, 2020a). In contrast, the ISSE survey in Ireland achieved a 29.3\% response rate in 2019, includes 67 questions written in third person as a series of statements, yet fails to ask if students are satisfied with their choice of HEI or course (ISSE, 2019).

The UK NSS has shown the greatest area of student dissatisfaction is in assessment and feedback; establishing good practice in this area is essential (Office for Students, 2020b; Unistats, 2007). Consequently, if lecturers design and implement assessment methods which enable academic support via formative feedback, students may be more inclined to avail of the learning opportunity (HEA Academy, 2010; ISSE, 2019).

The Equivalency Theorem suggests deep and meaningful learning is supported by a high level of interactivity in one of three forms of interaction: student-teacher, student-student, and student-content (Anderson, 2003). A learner's interaction with course content is the most important predictor of student satisfaction in a fully online course, specifically online course content related to personal experiences of students, help to increase student interaction with course content (Kuo et al., 2014). 


\subsection{Building Covenantal Relationships}

Covenantal relationships in education are crucial to creating bonds of trust between educators and students that facilitate learning and growth. Covenants contrast with contractual relationships, wherein students will merely aim to pass a course with good grades. Instead, covenantal relationships are founded in educators who communicate empathetically, listen deeply, and attempt to relate to students, thereby influencing action rather than dictating it (DeLong, 2020). These foundations can also be seen in the three levels of student engagement: build a rapport, communicate directly and be approachable (Fry et al., 2009). Educators invested in covenantal relationships are not afraid of being vulnerable, or of building relationships with students to instil loyalty within a secure environment in which they will learn (DeLong, 2020).

Reflective online diaries provide a safe space for students and educators to privately communicate; this opportunity to engage directly, is not always readily available in the higher education setting. Therefore, using this online environment to build covenantal relationships can help to overcome some of the challenges facing online learners connected to their isolation (Gillett-Swan, 2017). To have a meaningful impact it requires educators to fully engage; they should carefully read each learners contribution, listen to what is being said by the learner and reflect and respond with individual feedback for each learner. Finally, educators should consider what student reflections might infer about their own pedagogical approach. Ongoing reflective practice enables educators to progress, grow, respond to new ideas and to introduce innovation (Fry et al., 2009). Which in turn may improve student engagement with their learning and their overall satisfaction.

\section{Context}

Participants included students enrolled in a Sales and Customer Service module taught on the BA Honours Degree in Insurance Practice Apprenticeship programme delivered online by Institute of Technology, Sligo, Ireland with the Insurance Institute of Ireland as its industry partner. This unique three-year programme blends certified insurance practitioner examinations with business skills and 'on-the-job' learning. Apprentices are office based with a one day per week 'release' for live streamed lectures and case studies. The module lecturer utilised reflective online diaries for the apprentice students between 2016 and 2020 . To allow for variations in student learning, the assessment strategy for this 10-credit module comprised of four activities: reflective online diaries, a reflective practice report and presentation and a closed book examination. The weighted value attributed to reflective online diaries was 20 percent of student's overall module marks. Students were asked to write a 300-word reflective online diary entry within the virtual learning environment (VLE). The prompts provided to assist their reflective writing evolved over the four academic years, in response to student feedback. In the 2016-2017 academic year, the first cohort of apprentices were asked to write weekly reflective online diaries. From 2017-2018 on, the frequency was reduced to bi-weekly.

\section{Methodology}

While research exists on the use of ePortfolios and reflective online diaries in education, this paper addresses the deficit in empirical research on ePortfolio's use in Irish HEIs and explores their use in the context of an apprenticeship programme delivered online in Ireland 
(Farrell, 2018). Action research methodologies are commonly used by educators to gather information and subsequently improve how they teach and how their students learn (Mills, 2014). Action research allows the educator to turn the lens on their own educational practices through a dynamic process that spirals between self-reflection, data collection and action (Creswell, 2014). In line with this dynamic process, this study adopted a mixed methodology, collective of qualitative reflective practice and a quantitative survey of students. Analysing findings from both stakeholder perspectives resulted in triangulation of data and a significant contribution to literature relating to use of ePortfolios.

In completing the survey, students were consenting research participants. Students were advised data collected remained anonymous and was stored and protected in accordance with GDPR guidelines. Therefore, all parts of this research project adhered to, and complied with, best practice research guidelines recommended in Brydon-Miller's (2009) "covenantal ethics" commitment to open and transparent participation in action research.

\subsection{Reflective Practice Method}

Personal and professional reflections were documented to explore the pedagogical perspective of this study, therefore, addressing the need for more research which is focused on the faculty perspective and their attitudes towards online learning (Martin et al., 2017). Reflections were based on observation of student reflective online diary submissions, where output was new pedagogies for improved learning (Samaras, 2011). Reflection on ePortfolio use in higher education is well documented in the literature (Jenson 2011; Scholz et al., 2017; Wuetherick and Dickinson 2015). Critical reflection in a diary format is also common in education research (McTaggart et al., 2018). Personal reflections in this study were electronic in nature and were self-led, that is, entries were made when the researcher felt it was appropriate; most often, after reviewing a set of reflective online diaries. Further reflection took place at the end of each academic year upon review of the student survey findings.

Adopting Braun and Clarke's (2020) thematic analysis approach, the data analysis process involved familiarisation with the researchers own critical reflections to identify and code the data. This creative and active process led to the generation of themes and later, their meaning interpreted. The data analysis process was iterative, spiralling back and forth between data collection and analysis (Creswell, 2014). With the added sensitivity the researcher is the instructor implementing the ePortfolios, objectivity in analysis was essential.

\subsection{Student Survey Method}

The student perspective employed a descriptive research design (Malhotra, 2020). Students were asked to voluntarily complete the end of module survey on their final week enrolled in the module. Data was collected anonymously using online survey software, an appropriate method for students enrolled in an online programme. The survey link was accessible via the final reflective online diary submission page on the VLE. The total sample size for the study was 164 representing an overall response rate from all apprentice students enrolled on the Sales and Customer Service Module between 2016-17 and 2019-2020 of 61\%. 


\begin{tabular}{lcccc}
\hline & $\mathbf{1 6 - 1 7}$ & $\mathbf{1 7 - 1 8}$ & $\mathbf{1 8 - 1 9}$ & $\mathbf{1 9 - 2 0}$ \\
\hline Number of Students Enrolled on Module & 62 & 76 & 71 & 58 \\
Number of Survey Responses & 33 & 45 & 49 & 37 \\
Response rate & $53.2 \%$ & $59.2 \%$ & $69 \%$ & $63.8 \%$ \\
\hline
\end{tabular}

\section{Table 1: Breakdown of Response Rate by Cohort}

Surveys were designed to collect general module feedback and included five additional questions specific to the use of reflective online diaries. The scaling technique included multiple choice and Likert scales, concluding with one open-ended response question, giving apprentices an opportunity to provide additional feedback on the reflective online sales diaries.

For the quantitative approach within there are several stages to the analytical plan. At the first stage Spearman Rank-Order Correlations were employed to explore apprentices perceived level of satisfaction with reflective online diaries against key factors. Next, exploratory factor analysis was carried out to examine the psychometric structure of the student enhancement dimension, and finally, a path analysis using IBM AMOS v25 tested the Module Satisfaction and Student Enhancement Prediction Model. This model conceptualises the following factors: assessment value, manageability, frequency, student enhancement, module satisfaction and cohort (2016-17, 2017-18, 2018-19 and 2019-20) and are linked to literature in Appendix 1.

\section{Findings}

The research findings are presented in two sections; the first explores themes emerging from reflective practice, while the second phase explores the quantitative findings from the student survey.

\subsection{Reflective Practice Findings}

Reflective practice findings are presented within two themes identified from an analysis of the instructor's personal reflections: student enhancement and pedagogical benefits. An annual review of the end of semester student surveys identified three recurring themes requiring reflection from a pedagogical perspective: frequency, manageability, and assessment value.

\subsubsection{Student Enhancement}

In reading and responding to student's reflective online diaries, the lecturer recognised the progress in individual students' learning. It was evident which students were engaging well with the module and overall programme, and those who were disengaged or struggling. The ability to address issues directly before they became overwhelming for students was the obvious advantage of the reflective online diaries for the lecturer. On occasion, this led to one-to-one student meetings. Most students effectively communicated their understanding of the module with concise examples of how theory applied to their roles within the insurance industry. However, not all grasped reflective writing and simply wrote a summary of the lecture content. When necessary, the lecturer responded directly to those students, prompting them to be more reflective and explaining how it might be achieved. Those students were closely observed until their entries improved. 


\subsubsection{Pedagogical Benefits}

The benefits of the lecturers' personal reflections materialised subconsciously. Reading the reflective online diaries gave insight into the daily working lives of apprentices. Oftentimes, learners were asked to share their industry experience with peers, as a direct result of the lecturer having read the diary entry. The sharing of experiences encouraged a stronger sense of community within the student cohorts and ultimately created deeper engagement with the module content. It also ensured students remained alert during lectures, unknowing if their experiences would be called upon at any stage. The lecturer felt a stronger connection to students as a direct result of the reflective online diaries (Gillett-Swan, 2017). In traditional classroom-based teaching, it is inevitable the educator learns a little bit about each of their students', this information can then be used to personalise delivery. While not always possible in the online context, the reflective online diaries fostered the ability to personalise delivery and develop a connection. As a result, rapport developed with students, which in turn inspired trust and perhaps improved student retention.

\subsubsection{Frequency}

Despite apprenticeship students engaging well with the reflective online diaries, there were some objections regarding their frequency. During the first year of their implementation students completed weekly reflective online diaries, this frequency seemed appropriate to encourage structure and routine early on, particularly for first year students. In 2017-18 the frequency was reduced to biweekly for the second and latter cohorts, with a total of 7 submissions over the course of the semester. Changes were considerate of overall apprentice workload, student feedback within their reflective online diaries, and findings from the annual student survey.

\subsubsection{Manageability}

Assessment strategies such as reflective online diaries, where students gain recognition for their engagement with a module, encourages them to become familiar with reflective writing. Prompts are an effective way to support reflection in writing (Fry et al., 2009). Initially, students were provided relatively vague and open prompts, the intention in being less prescriptive, was for students to craft their entries based on their personal interpretation of the module content delivered each week. However, following feedback the prompts were refined and customised with more specificity to module content, thus providing more guidance for the second cohort. In 2017-18 it became evident not all apprentices were able to apply the sales and customer service module content to their existing industry role. Those not actively working in a customer facing role struggled to reflect on the content even with enhanced prompts. Whilst this group comprised a small proportion of each student cohort, in 2018-19 onwards prompts were developed further to be more inclusive for all apprentices.

Initially, the lecturer intended to respond to each individual reflective online diary entry every week, however, with between 58-76 students in each cohort the amount of time required to read and respond to each one was underestimated. After four weeks it was decided feedback would only be provided to students who had posed a question or those struggling with the concept of reflection. Alas, subsequent findings from surveys suggested students would like a response for every reflective online diary entry. Therefore, from 201718 onwards the lecturer reverted to individual responses. Given the reduction in diary frequency, this level of feedback became more manageable and students with a greater need for a response were prioritised. 


\subsubsection{Assessment Value}

The weighted value attributed to reflective online diaries was $20 \%$ of overall module marks. Students could either pass or fail, achieving either zero or $20 \%$. Some student feedback requested a revision of this and sought individual grading of student diaries. However, in line with other work-based learning reflective assessments on the programme, the pass/fail grading remained unchanged.

\subsection{Student Survey Findings}

The quantitative data analysis employed identified correlations between cohort and key variables, associations between cohort and frequency of completion, and finally estimates a reflective online diary apprenticeship satisfaction model which predicts module satisfaction through student enhancement and other key factors.

\subsubsection{Correlations between cohort and key variables}

Spearman (Rho) Rank-Order Correlations are presented in Table 2 where it is clear the strongest significant relationship was with apprentices' overall satisfaction with the module; data suggests newer intakes (Cohorts) to the apprenticeship were moderately more likely to be satisfied with the course than those from earlier intakes $\left(r_{s}=-.338, \mathrm{p}<.05\right)$. This trend was also reported when it came to their overall engagement with the programme $\left(r_{s}=-.315\right.$, $\mathrm{p}<.05)$, learning $\left(r_{s}=-.302, \mathrm{p}<.05\right)$, with the module $\left(r_{s}=-.299, \mathrm{p}<.05\right)$, their performance at work $\left(r_{s}=-.261, \mathrm{p}<.05\right)$ and reflective thinking skills $\left(r_{s}=-.245, \mathrm{p}<.05\right)$. Any of the other student enhancement factors failed to reach statistical significance. Furthermore, cohort status failed to have a significant relationship with their perception around manageability and assessment value. The findings support the importance of module satisfaction for students but also identify there are key student enhancement indicators.

\begin{tabular}{ll}
\hline Survey Items & Cohort \\
\hline Module Satisfaction & $-.338^{* *}$ \\
Overall, how satisfied are you with the 'Sales and Customer Service for Insurance Products' & \\
module? & .138 \\
Manageability & -.036 \\
How difficult/easy did you find it to keep up to date with the bi-weekly online sales diary? & \\
Assessment Value & \\
The online sales diaries were worth $20 \%$ of your total module marks. Do you think this & $-.302^{* *}$ \\
weighting was... & $-.299^{* *}$ \\
Student Enhancement & $-.315^{* *}$ \\
The online sales diaries enhanced my.... & -.145 \\
overall learning & $-.261^{* *}$ \\
level of engagement with the module & $-.245^{* *}$ \\
level of engagement with the overall programme & -.153 \\
ability to complete my sales project & \\
performance at work & \\
reflective thinking skills & \\
The online sales diaries helped me to apply lecture/tutorial content & \\
\hline & $* *$ Correlation is significant at the 0.01 level (2-tailed). *. Correlation is significant at the 0.05 level $(2-$ tailed).
\end{tabular}

Table 2: Correlates of Academic Cohort 


\subsubsection{Association between cohort and frequency of completion}

Table 3 presents the descriptive breakdown between cohorts and their perceptions around frequency of reflective online diary completion. The frequency of submission was reduced to biweekly from the second cohort onwards; the findings interestingly report after the first cohort, most of the apprentices indicated the frequency was not an issue. This association was reported to be statistically significant $\left(\chi^{2}(6)=14.145, \mathrm{p}<.05\right)$ with a small effect size (Cramer's $V=.219$ ).

\subsubsection{Exploring the factor structure of Student Enhancement}

An exploratory factor analysis (EFA) using Principle Axis Factoring with Direct Oblimin was employed; factors with Eigenvalues over 1 are reported. A one factor emerged and accounted for $60.11 \%$ of variance explained. Results in Table 4 indicate all seven items had a factor loading above the .4 level (Field, 2017). Thus, all the student enhancement items fell into one factor with a very satisfactory associated internal consistency $(\alpha=.89)$ (Kline, 2000).

\begin{tabular}{|c|c|c|c|c|c|}
\hline \multirow{2}{*}{ Cohort } & & \multicolumn{2}{|c|}{ Frequency } & \multirow[b]{2}{*}{ Total } & \\
\hline & & Yes & No & & \\
\hline \multirow[t]{3}{*}{$16-17$} & $\mathrm{~N}$ & 16 & 12 & 28 & \\
\hline & $\%$ Cohort & $57.1 \%$ & $42.9 \%$ & $100 \%$ & \\
\hline & $\%$ Frequency & $32.0 \%$ & $13.8 \%$ & & \\
\hline \multirow[t]{3}{*}{$17-18$} & $\mathrm{~N}$ & 15 & 24 & 39 & \\
\hline & $\%$ Cohort & $38.5 \%$ & $61.5 \%$ & $100 \%$ & \\
\hline & $\%$ Frequency & $30.0 \%$ & $27.6 \%$ & & \\
\hline \multirow[t]{3}{*}{$18-19$} & $\mathrm{~N}$ & 14 & 28 & 42 & \\
\hline & $\%$ Cohort & $33.3 \%$ & $66.7 \%$ & $100 \%$ & \\
\hline & $\%$ Frequency & $28.0 \%$ & $32.2 \%$ & & \\
\hline \multirow[t]{3}{*}{$19-20$} & $\mathrm{~N}$ & 5 & 23 & 28 & \\
\hline & $\%$ Cohort & $17.9 \%$ & $82.1 \%$ & $100 \%$ & \\
\hline & $\%$ Frequency & $10.0 \%$ & $26.4 \%$ & & \\
\hline \multirow[t]{2}{*}{ Total } & $\mathbf{N}$ & $\mathbf{5 0}$ & 87 & 137 & \\
\hline & $\%$ Cohort & $36.5 \%$ & $63.5 \%$ & $100 \%$ & \\
\hline \multicolumn{6}{|c|}{ Table 3: Association between Cohorts and Frequency of Completion } \\
\hline \multicolumn{5}{|c|}{ Student Enhancement Items } & Loadings \\
\hline \multicolumn{5}{|c|}{ The online sales diaries helped me to apply lecture/tutorial content } & 799 \\
\hline \multicolumn{5}{|c|}{ The online sales diaries enhanced my overall learning } & 772 \\
\hline \multicolumn{5}{|c|}{ The online sales diaries enhanced my level of engagement with the module } & 768 \\
\hline \multicolumn{5}{|c|}{ The online sales diaries improved my performance at work } & 746 \\
\hline \multirow{2}{*}{\multicolumn{5}{|c|}{$\begin{array}{l}\text { The online sales diaries enhanced my level of engagement with the overall programme } \\
\text { The online sales diaries improved my ability to complete my sales project }\end{array}$}} & 734 \\
\hline & & & my sal & & 653 \\
\hline \multicolumn{5}{|c|}{ The online sales diaries enhanced my reflective thinking skills } & .639 \\
\hline \multicolumn{5}{|c|}{$\%$ of Variance Explained } & 60.11 \\
\hline \multirow{2}{*}{\multicolumn{5}{|c|}{$\begin{array}{l}\text { Eigenvalues } \\
\text { Alpha coefficient }\end{array}$}} & 4.21 \\
\hline & & & & & .89 \\
\hline
\end{tabular}

Table 4: Factor structure of student enhancement 


\subsubsection{Estimation of the reflective online diary apprenticeship satisfaction model}

Path analysis tested the predictors of the module satisfaction model (Figure 1) and the overall fit of the model suggested a good explanation of the relationships within the data $\left(X^{2}(164)=\right.$ $5.421, d f=4, p=.247, X^{2} / d f=1.355$, RMSEA $\left.=.047\right)$. The Chi-Square value with associated degrees of freedom were low and non-significant, all values associated with the $X^{2} / d f$ ratio were less than 3 (Kline, 2016); and the RMSEA was less than .050 (Browne and Cudeck, 1993; Hu and Bentler, 1999). Incremental fit indices were employed to evaluate the model fit (Hoyle and Panter, 1995; Hu and Bentler, 1999; Kline, 2016; Miles and Shevlin, 2007). The values indicated the NFI (.957), CFI (.986), and IFI (.988), TLI (.926) were all greater than the .95 cut off point; and provided a good approximation and explanation of the data (Kline, 2016; Miles and Shevlin, 2007).

Figure 1 illustrates the predictor variable influences on student enhancement and overall module satisfaction. Exploring the model further, only two of the predictors had an impact on student enhancement; namely frequency $(B=-.184, p<.05)$ and cohort $(B=-.266, p<.001)$. Both predictors had a weak inverse, yet significant, influence on apprentice student's enhancement attitudes, suggesting more favourable enhancement attitudes were related to a more favourable view about the frequency of the reflective online diary assessment tool and being more recently an enrolled cohort on the module. Perceptions about the assessment value and its manageability failed to impact on their enhancement attitudes. These factors accounted for $19.3 \%\left(\mathrm{R}^{2}=.193\right)$ of variance student enhancement perceptions. Finally, student enhancement significantly predicted overall module satisfaction suggesting those with more favourable student enhancement perceptions, were more likely to be satisfied overall with the module $(\beta=-.586, \mathrm{p}<.001)$; accounting for $34.3 \%\left(\mathrm{R}^{2}=.343\right)$ of variance explained.

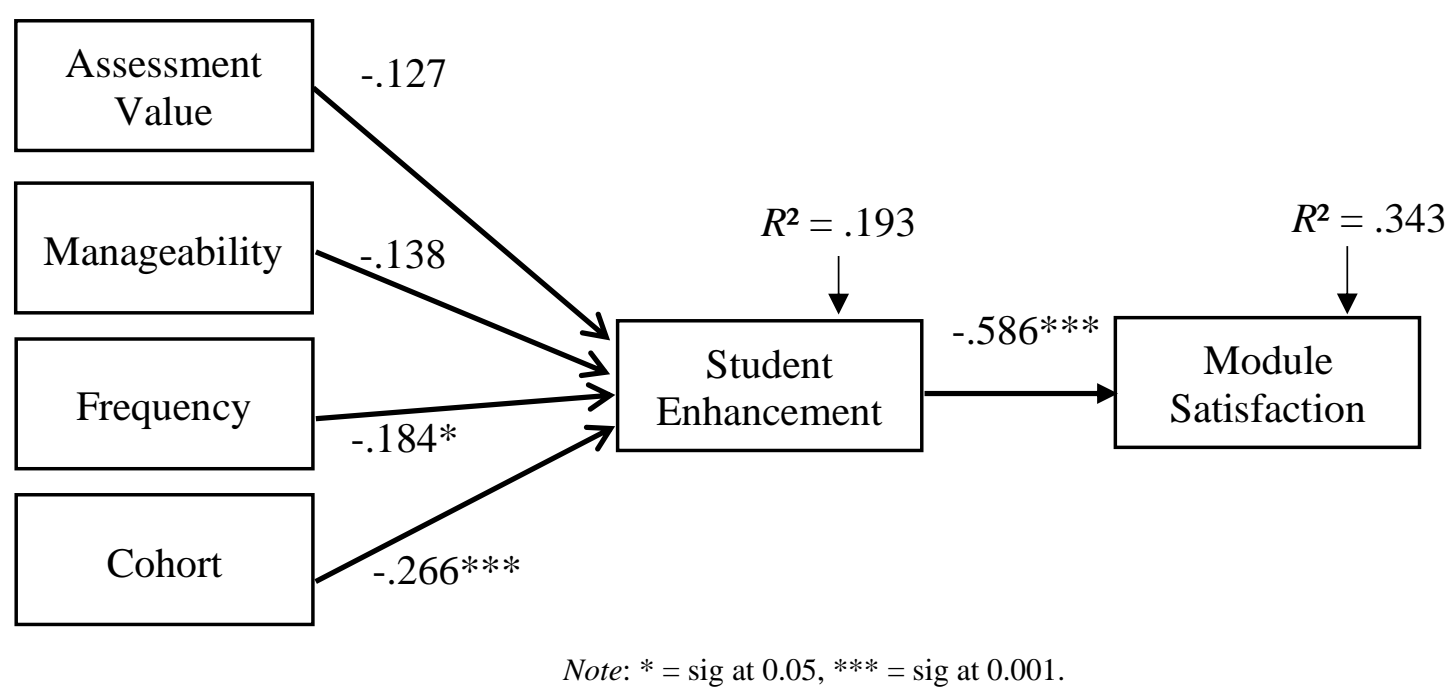

Figure 1: Module Satisfaction and Student Enhancement Prediction Model

\section{Discussion}

The aim of this research was to explore if reflective online diaries can enhance teaching, learning and assessment in the context of an apprenticeship programme delivered online. Findings provide evidence to generate a discussion regarding past research and generate both implications and recommendations for educational practice and future research. 


\subsection{Student Enhancement Through Reflective Online Diaries}

The findings indicate there are many key items which comprise the concept of Student Enhancement suggesting using a single item approach is inadequate to gauge its breadth. Where reflective online diaries were used as an assessment tool in an apprenticeship programme delivered online, this study identifies seven key items strongly related to Student Enhancement. These items support a more multi-faceted approach and include learner's interaction with course content, learner-task interaction (Anderson, 2003; Kuo et al., 2014; QQI, 2013), learner engagement with the module and overall programme (QQI, 2013), learner reflective thinking skills (QQI, 2014), enhanced on the job performance for apprentice learners (Farrell, 2018; QQI, 2014) and overall student learning (QQI, 2013). Little research has explored student enhancement in such a manner within online learning and in using assessment activities such as reflective online diaries (Farrell and Seery, 2019). The reflective practice findings show reflective online diaries assist in identifying learners who are disengaged with the module. Early identification allows the instructor to intervene, and if successful then overall student enhancement can be salvaged. Thus, the use of reflective online diaries in an online apprenticeship programme have been shown to enhance student learning experiences within this study. This finding addresses a gap in literature related to the potential positive impact of ePortfolios on student learning (Donaldson, 2018).

\subsection{Predicting Module Satisfaction Through Reflective Online Diaries}

To date, little research has approached predicting module satisfaction and student enhancement through a tested conceptual framework as proposed in this study. Overall, the model provided a good explanation of the data. It is envisaged student enhancement has a crucial role in predicting student satisfaction with the module; in other terms, the more an apprentice learner perceives a reflective assessment activity will inform different areas of their overall learning, both within the programme and at work, the more likely they are to be satisfied with the module (Kuo et al., 2014). The implications suggest employing an assessment technique such as reflective online diaries, not only has an impact on the module, but also in other areas of the programme and within the apprentice's role in industry. Therefore, the use of reflective online diaries in an online apprenticeship programme have been shown to enhance student assessment perceptions within this study.

An interesting finding from the model, is both manageability and assessment value were not important predictors of student enhancement; in other terms, both these factors had little weighting on how apprentice students thought the reflective online diary assessment tool was enhancing them. Rather, what did significantly impact student enhancement within the model was the frequency of diary completion and the cohort of the course, suggesting practical elements of the assessment were more important than internal attributes. The model also illustrates newer cohorts were moderately more likely to be satisfied with the course than those from earlier intakes, signalling modifications made to reflective online diaries over four years positively influenced overall module satisfaction.

In designing modular assessment strategies, the instructor should consider the frequency of submission and weigh up the overall workload for learners across all modules on a programme (QQI, 2013). These findings point to the importance of HEIs enabling programme teams to design programme assessment strategies which consider the enhancement of student learning both within and outside the programme, where the outcome leads to enhanced student satisfaction. 


\subsection{Pedagogical Enhancement Through Reflective Online Diaries}

Learners should be involved in the periodic review of assessment procedures (QQI, 2013). This study actively involved learners in the evaluation of reflective online diaries as an assessment tool within a module delivered in an online apprenticeship programme by seeking their feedback annually. However, the final step in action research requires educators to act on the feedback acquired from data collection (Creswell, 2014). If student feedback is acted on in a collaborative way, then rapport and engagement can be improved, with subsequent enhancements in teaching, learning and assessment to follow (DeLong, 2020). Manageability did not impact student enhancement in this study. However, it did emerge as an important factor within the educator's reflective practice, where the amount of time required to facilitate a new assessment tool was underestimated. This study took place over four years allowing the researcher to thoroughly explore the use of reflective online diaries as an assessment tool. Many changes were implemented during that time and ultimately the findings demonstrate the time invested into critical reflective practice on one's own pedagogy can lead to an enhancement in teaching (Gillett-Swan, 2017). Reflecting on student feedback enhanced the educator's confidence, the confidence acquired in the assessment tool led to a sharing of knowledge with peers. Thus, it is concluded the use of reflective online diaries in an online apprenticeship programme have been shown to enhance teaching within this study.

\section{Limitations and Suggestions for Future Research}

The limitations of this study are noted, in that the reflective practice findings are based on one educator's experience of the assessment tool; and participants in the student survey came from within one Irish HEI. In future research, a more diverse learner population, such as full time, on-campus learners, should be included to determine if the factors within the model presented would have a similar outcome.

\section{Conclusion and Implications}

This study found reflective online diaries can enhance teaching, learning and assessment in the context of an apprenticeship programme delivered online. By linking the educators reflective practice findings with the student survey outcomes, the paper builds on prior research connected to teaching, learning and assessment and the role of ePortfolios in achieving enhancement in these areas.

The purpose of using reflective online diaries in this module were 1) to provide a formal way to credit students for recognising the value of their learning, 2) to check students were engaged with the module content, 3 ) to facilitate interaction between the lecturer and student thereby foster a relationship; and 4) to enhance the learning experience of students. The findings indicate these objectives were achieved and reflective online diaries are an effective way to support reflective practice in the context of an online apprenticeship programme. The conceptualised model derived from path analysis shows student enhancement has a role in predicting student satisfaction with the module; the more an apprentice learner perceives a reflective assessment activity will inform areas of their overall learning, the more likely they are to be satisfied with the module (Kuo et al., 2014).

This research significantly adds to growing evidence that ePortfolio based learning has the potential to support many higher education objectives connected to achievement of 
knowledge, skills, and competence by third level learners in Ireland. Instructors therefore must envisage more innovative types of assessment that offer transferability in other areas such as reflective online diaries. It is clear learners view this transferability as a key driver of their academic satisfaction. Whilst the value of the assessment and its manageability did not impact student enhancement attitudes within the model, the frequency of reflective online diary submission was a factor of influence. As the years progressed in this study, so too did module satisfaction among student cohorts, indicating modifications made to reflective online diaries over four years were successful.

Reflective online diaries have demonstrated their role in overcoming many well documented challenges associated with online teaching and learning including, learner isolation, lack of interaction and absence of learning community support. Highlighting the central role of the educator on a student's learning experience, the reflective online diaries proved as an effective means to foster a relationship with apprentice learners (Gillett-Swan, 2017); their ability to provide one-to-one feedback addresses student's greatest area of dissatisfaction; assessment and feedback (Office for Students, 2020b). This study also recognises "technology does not teach students; effective teachers do" (Whitesel, 1998; cited in McTaggart et al., 2018). Consistent reflective practice therefore supports teachers to develop their pedagogy and maintain their effectiveness (Gillett-Swan, 2017).

The benefits of critical reflective practice for educators have been reinforced in this study. The active engagement of students in the review of assessment methods created a rapport within the online learning community and enhanced the educator's confidence in their choice of assessment strategy. This study highlights the main constraint for the educator was the time required to facilitate a new assessment tool. To support implementation of new assessment strategies, HEIs must create opportunities for lecturers test new assessment methods. This facilitation will enable lecturers to cope with emerging challenges such as those presented in online teaching and learning (QQI, 2013).

In conclusion, the implication of this study is that policymakers focused on improving quality assurance need to rethink how they can enhance the teaching and learning environment for students. This research is timely in its publication given the rapid digital transformation of HEIs due to the COVID19 pandemic. The theoretical and practical contributions are especially relevant as they provide evidence that usage of reflective online diaries are an effective and valuable means of assessing learners in an online programme, where physical engagement is not available. 


\section{References}

Anderson, T. (2003). Getting the Mix Right Again: An updated and theoretical rationale for interaction. International Review of Research in Open and Distance Learning, 4(2), 1-14.

Aslanian, C. B., \& Clinefelter, D. L. (2013). Online college students 2013: Comprehensive data on demands and preferences. Louisville, KY: The Learning House, Inc.

Boud, D., Keogh, R., \& Walker, D. (1985). Reflection: Turning Experience into Learning, London: Kogan Page.

Braun, V., \& Clarke, V. (2020). One size fits all? What counts as quality practice in (reflexive) thematic analysis? Qualitative Research in Psychology. doi:

10.1080/14780887.2020.1769238

Browne, M. W., \& Cudeck, R. (1993). Alternative ways of assessing model fit. In Bollen, K. A. \& Long, J. S., (Eds), Testing Structural Equation Models, (pp. 136-162). Beverly Hills, CA: Sage.

Brydon-Miller, M. (2009). Covenantal Ethics and Action Research. In Mertens and Ginsberg P. E., (Eds.), The Handbook of Social Research Ethics (pp. 243-258). Los Angeles, CA:

Sage.

Carlile, O., \& Jordan, A. (2005). It works in practice but will it work in theory? The theoretical underpinnings of pedagogy. AISHE, 1(1), 11-26.

Chen, H. L., \& Black, T. (2010). Using ePortfolio to support an undergraduate learning career: an experiment with academic advising, Educause Review. Retrieved from: https://er.educause.edu/articles/2010/12/using-ePortfolios-to-support-an-undergraduatelearning-career-an-experiment-with-academic-advising.

Chen, H. L., Grocott, L., \& Kehoe, A. (2016). Changing Records of Learning through Innovations in Pedagogy and Technology, Educause Review. Retrieved from: https://er.educause.edu/articles/2016/3/changing-records-of-learning-through-innovations-inpedagogy-and-technology.

Creswell, J. (2014). Educational Research: Planning, Conducting, and Evaluating Quantitative and Qualitative Research. Saddle River, NJ: Prentice Hall.

DeLong, T. J. (2020). Why Your Students Need to Know You're All In: Moving Beyond Knowledge Transactions to Learning Covenants', Harvard Business Publishing Education. Retrieved from: https://hbsp.harvard.edu/inspiring-minds/why-your-students-need-to-knowyoure-all-in.

Department of Education and Skills (2011). National Strategy for Higher Education to 2030 Report of the Strategy Group Report of the Strategy Group. Retrieved from: https://www.education.ie/en/Publications/Policy-Reports/National-Strategy-for-HigherEducation-2030-Summary.pdf. 
Donaldson, L., Buckley, K., Farrell, O., \& Uí Choistealbha, J. (2018). Reflections on ePortfolio Professional Learning: Harnessing an Unconference Approach. AePR, 2(3), 20-29. Retrieved from: https://aaeeblorg.files.wordpress.com/2018/11/aepr-v2n3.pdf.

Farrell, O. (2018). Failure to launch: The Unfulfilled Promise of EPortfolios in Irish Higher Education: An Opinion Piece. Dublin Business School Business Review, 2, 154-163. doi: 10.22375/dbr.v2i0.30

Farrell, O., \& Seery, A. (2019). I am not simply learning and regurgitating information, I am also learning about myself': learning portfolio practice and online distance students. Distance Education, 40(1), 76-97. doi: 10.1080/01587919.2018.1553565

Field, A. (2017). Discovering Statistics Using SPSS. Fifth Edition. London: Sage Publications Ltd.

Fry, H., Ketteridge. S., \& Marshall, S. (2009). A Handbook for Teaching and Learning in Higher Education: Enhancing Academic Practice. Third Edition. New York: Routledge.

Generation Apprenticeship. (2021). Apprenticeship Directory, Retrieved from: https://apprenticeship.ie/more/apprenticeship-directory.

Gillett-Swan, J. (2017). The Challenges of Online Learning: Supporting and Engaging the Isolated Learner. Journal of Learning Design, 10(1), 20-30. doi: 10.5204/jld.v9i3.293

HEA Academy. (2010). Student Engagement Literature Review. Retrieved from: https://www.heacademy.ac.uk/system/files/StudentEngagementLiteratureReview_1.pdf

Hoyle, R. H., \& Panter, A. T. (1995). Writing about structural equation models. In R.H. Hoyle (Eds.), Structural Equation Modelling: Concepts, Issues, and Applications. (pp. 158176). Thousand Oaks, CA: Sage Publications.

Hu, L., \& Bentler, P. (1999). Cut-off criteria for fit indexes in covariance structure analysis: Conventional criteria versus new alternatives. Structural Equation Modeling, 6(1), 1-55. doi: $10.1080 / 10705519909540118$

ISSE. (2019). Student Survey National Report 2019, Retrieved from: https://studentsurvey.ie/reports/studentsurveyie-national-report-2019.

Jenson, J. (2011). Promoting self-regulation and critical reflection through writing students' use of electronic portfolio. International Journal of ePortfolio, 1(1), 49-60. Retrieved from: https://eric.ed.gov/?id=EJ1107586.

Kline, R. B. (2016). Principles and Practice of Structural Equation Modeling. Fourth Edition. New York, NY: The Guilford Press.

Kline, P. (2000). The handbook of psychological testing. Second Edition. London: Routledge.

Kuo, Y. C., Walker, A. E, Schroder, K. E. E., \& Belland, B. R. (2014). Interaction, Internet self-efficacy, and self-regulated learning as predictors of student satisfaction in online 
education courses. The Internet and Higher Education, 20, 35-50. doi:

https://doi.org/10.1016/j.iheduc.2013.10.001.

Malhotra, N. K. (2020). Marketing research-An applied orientation. Seventh Edition. New Jersey: Prentice Hall International.

Martin, F., Ahlgrim-Delzell, L., \& Budhrani, K., (2017). Systematic Review of Two Decades (1995 to 2014) of Research on Synchronous Online Learning. American Journal of Distance Education, 31(1), 3-19. doi: 10.1080/08923647.2017.1264807

McTaggart, B., Doherty, A., O’Murchu, C., \& Colleary, S. (2016). Becoming Engaged: A Big Day Out or Repent at Leisure? Researching, Advancing \& Inspiring Student Engagement Conference. University of Loughborough, 2016. UK.

McTaggart, B., Doherty, A., O’Murchu, C., \& Colleary, S. (2018). A Road Less Travelled, A Road Nonetheless. The All Ireland Journal of Teaching and Learning in Higher Education (AISHE), 10(3). Retrieved from: https://ojs.aishe.org/index.php/aishe$\mathrm{j} /$ article/download/341/623/1751

Miles, J. N. V., \& Shevlin, M. (2007). A time and a place for incremental fit indices. Personality and Individual Differences, 42(5), 869-874. doi:

10.1016/j.paid.2006.09.22

Mills, G. E. (2014). Action Research: A Guide for the Teacher Researcher. UK: Pearson Education.

Moon, J. (2010). Learning Journals \& Logs, Reflective Diaries. Centre for Teaching \& Learning, Good Practice in Teaching \& Learning. University College Dublin. Retrieved from: https://ar.cetl.hku.hk/pdf/ucdtla0035.pdf.

Naidu, S. (2019). The changing narratives of open, flexible and online learning, Distance Education, 40(2), 149-152. doi: 10.1080/01587919.2019.1612981.

National Student Survey (NSS). (2020). NSS Core Questionnaire, Retrieved from: https://www.thestudentsurvey.com/content/NSS2020_Core_Questionnaire.pdf.

Nicol, D. J., \& Macfarlane-Dick, D. (2006). Formative assessment and self-regulated learning: A model and seven principles of good feedback practice. Studies in Higher Education, 31(2), 199-218. doi: https://doi.org/10.1080/03075070600572090

Office for Students. (2020a). National Student Survey - NSS. Retrieved from: https://www.officeforstudents.org.uk/advice-and-guidance/student-information-anddata/national-student-survey-nss/.

Office for Students. (2020b). Student satisfaction stable as data continues to highlight need for clear communication. Retrieved from: https://www.officeforstudents.org.uk/news-blogand-events/press-and-media/student-satisfaction-stable-as-data-continues-to-highlight-needfor-clear-communication/. 
QQI. (2013). Assessment and Standards, Revised 2013. Retrieved from:

https://www.qqi.ie/Publications/Publications/Assessment_and_Standards\%20Revised\%2020 13.pdf.

QQI. (2014). Awards Standards - Generic Higher Education and Training. Retrieved from: https://www.qqi.ie/Publications/Publications/Generic\%20Major\%20Awards\%20\%20QQI\%20Awards\%20Standards.pdf.

QQI. (2016). Statutory Quality Assurance Guidelines developed by QQI for use by all Providers. Retrieved from:

https://www.qqi.ie/Downloads/Core\%20Statutory\%20Quality\%20Assurance\%20Guidelines. pdf.

Race, P. (2020). The Lecturers Toolkit, A Practical Guide to Assessment, Learning and Teaching. Fifth Edition. London: Routledge.

Samaras, A. (2011). Flying solo: Teachers take charge of their learning through self-study research. Learning Forward. Journal of Staff Development, 32, 42-45.

Scholz, K, Tse, C., \& Lithgow, K. (2017). Unifying Experiences: Learner and Instructor Approaches and Reactions to ePortfolio Usage in Higher Education. International Journal of ePorfolio, 7(2), 139-150. Retrieved from: https://eric.ed.gov/?id=EJ1159901

Unistats. (2007). The college and university comparison site. Retrieved from: http://www.unistats.co.uk.

Williams, J. (2016). Quality assurance and quality enhancement: is there a relationship? Quality in Higher Education, 22(2), 97-102. doi: 10.1080/13538322.2016.1227207

Wuetherick, B., \& Dickinson, J. (2015). Why ePortfolios? Student Perceptions of ePortfolio Use in Continuing Education Learning Environments. International Journal of ePortfolio, 5(1), 39-53. Retrieved from: https://files.eric.ed.gov/fulltext/EJ1107862.pdf. 
Appendix 1 Factors Linkage to Literature

\begin{tabular}{|c|c|}
\hline Factor & Citation \\
\hline Assessment Value & QQI (2013) \\
\hline Manageability & Race (2020) and \\
\hline QQI (2013)
\end{tabular}

